\title{
Building national emission inventories for the energy sector: Implications for life cycle assessment and nations environmental footprinting
}

\author{
Leclerc, Alexandra Segolene Corinne; Hauschild, Michael Zwicky; Wood, Richard; Laurent, Alexis
}

Published in:

Science of the Total Environment

Link to article, DOI:

10.1016/j.scitotenv.2019.135119

Publication date:

2020

Document Version

Peer reviewed version

Link back to DTU Orbit

Citation (APA):

Leclerc, A. S. C., Hauschild, M. Z., Wood, R., \& Laurent, A. (2020). Building national emission inventories for the energy sector: Implications for life cycle assessment and nations environmental footprinting. Science of the Total Environment, 708, [135119]. https://doi.org/10.1016/j.scitotenv.2019.135119

\section{General rights}

Copyright and moral rights for the publications made accessible in the public portal are retained by the authors and/or other copyright owners and it is a condition of accessing publications that users recognise and abide by the legal requirements associated with these rights.

- Users may download and print one copy of any publication from the public portal for the purpose of private study or research.

- You may not further distribute the material or use it for any profit-making activity or commercial gain

- You may freely distribute the URL identifying the publication in the public portal 


\section{Journal Pre-proofs}

Building national emission inventories for the energy sector: Implications for life cycle assessment and nations environmental footprinting

Alexandra Leclerc, Michael Z. Hauschild, Richard Wood, Alexis Laurent

PII:

S0048-9697(19)35111-3

DOI: https://doi.org/10.1016/j.scitotenv.2019.135119

Reference: STOTEN 135119

To appear in: $\quad$ Science of the Total Environment

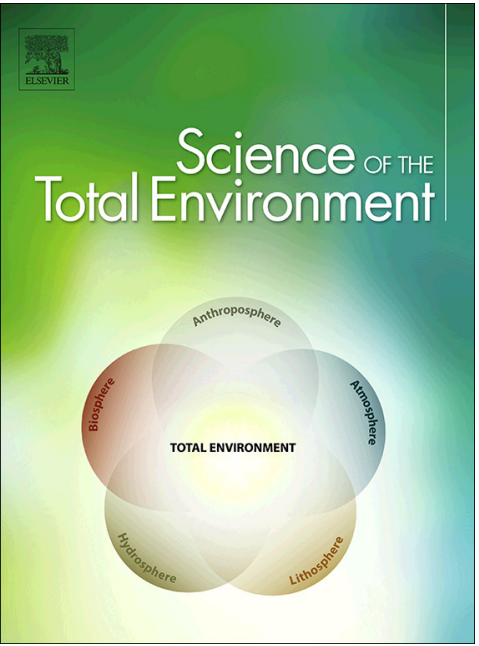

Received Date: $\quad 12$ July 2019

Revised Date: $\quad 14$ October 2019

Accepted Date: $\quad 21$ October 2019

Please cite this article as: A. Leclerc, M.Z. Hauschild, R. Wood, A. Laurent, Building national emission inventories for the energy sector: Implications for life cycle assessment and nations environmental footprinting, Science of the Total Environment (2019), doi: https://doi.org/10.1016/j.scitotenv.2019.135119

This is a PDF file of an article that has undergone enhancements after acceptance, such as the addition of a cover page and metadata, and formatting for readability, but it is not yet the definitive version of record. This version will undergo additional copyediting, typesetting and review before it is published in its final form, but we are providing this version to give early visibility of the article. Please note that, during the production process, errors may be discovered which could affect the content, and all legal disclaimers that apply to the journal pertain.

(C) 2019 Elsevier B.V. All rights reserved. 


\title{
Building national emission inventories for the energy sector: Implications for life cycle assessment and nations environmental footprinting
}

\author{
Alexandra Leclerc ${ }^{1,}{ }^{*}$, Michael Z. Hauschild ${ }^{1}$, Richard Wood $^{2}$, Alexis Laurent ${ }^{1}$ \\ ${ }^{1}$ Quantitative Sustainability Assessment Group, Sustainability Division, DTU Management, Technical University of \\ Denmark, Lyngby, Denmark \\ ${ }^{2}$ Industrial Ecology Programme, Department of Energy and Process Engineering, Norwegian University of Science \\ and Technology, Trondheim, Norway \\ *Corresponding author: ascl@dtu.dk; tel: (+45) 452547 29; Produktionstorvet, Bygning 424, R207, 2800 Kongens \\ Lyngby, Denmark.
}

\begin{abstract}
Environmentally-extended multi-region input-output (EE-MRIO) models allow calculating environmental impacts of goods and services in a supply-chain perspective. However, current EE-MRIO databases only have limited coverage of toxic pollutant emissions. This limited coverage is caused by the fact that public emission databases currently provide a rather modest pollutant coverage, are restricted to a limited number of countries, and lack differentiation in terms of sectors. This therefore calls for alternative data sources and inventorying techniques. Using the production of heat and electricity as a case study, we investigate the usability of available process-based inventories like the ecoinvent database from the field of Life Cycle Assessment (LCA) to build national emission inventories of pollutants. We thus develop the ecoinvent-based National Energy-related Emission (ENEE) inventory, comprising a total of 231 airborne emissions and 87 waterborne emissions of pollutants from heat and
\end{abstract}


electricity power plants in 140 countries over the period 1995-2014. Using the improved data sets, we demonstrate that extending the coverage of pollutants beyond the few commonly-reported ones, like greenhouse gases, has a significant influence on the quantification of other important environmental impacts such as ionizing radiation and impacts of toxic substances to freshwater ecosystems. The ENEE inventory is an important first step towards building comprehensive inventories of pollutant emissions from power and heat generation, thus enabling more complete assessments of the energy sector. It also exemplifies the gains that can be made when introducing process-based data to complement public national and sectoral data for life cycle assessments and nations environmental footprinting.

\section{Introduction}

Our current consumption of resources has been demonstrated to be unsustainable (Steffen et al., 2015), and several governments and international organizations such as the United Nations have highlighted the need to transform society and ensure sustainable production and consumption patterns (United Nations, 2016). More specifically, UN's Sustainable Development Goal no.12 aims to “achieve the sustainable management of natural resources" and to "reduce the releases to air, water and soil [of chemicals] in order to minimize their adverse impacts on human health and the environment". By combining economic data on international trade and environmental statistics on resource consumption or pollutant emissions, Environmentally-Extended Multi-Regional Input-Output (EE-MRIO) models can help quantify from a consumption perspective the pressure exerted on the environment by human activities (Mattila, 2018; Wiedmann, 2009). EE-MRIO models hence allow investigating the decoupling of economic growth from environmental impacts (Prell et al., 2014; Schandl et al., 2016). Whereas these models have historically mostly focused on greenhouse gases, water use, land use or material consumption, they recently tend to include other environmental pressures such as the releases of nitrogen or toxic substances (Oita et al., 2016; Persson et al., 2019), and to account for the 
environmental consequences (i.e. the impacts) of these pressures (Verones et al., 2017). Such developments are indeed necessary to ensure assessments that encompass all environmental impacts, and decrease the risks of burden shifting (Fang and Heijungs, 2015; Laurent et al., 2012). In its latest version (v. 3), the EE-MRIO model EXIOBASE, designed for environmental assessment purposes, comprises 33 individual pollutants, including the emissions to air of 9 metals and 5 persistent organic substances. However, as highlighted by Beylot et al. (2019), this available coverage is insufficient to support a comprehensive and fair assessment of all the environmental impacts of countries, and an expansion is required, in particular with data on emissions of toxic and radioactive substances.

Data availability remains however a problem. Whereas some databases exist for developed countries, they are typically lacking for developing economies. In addition, national emission databases are currently often restricted to a narrow coverage of substances over a limited timespan (Cucurachi et al., 2014). Progress can be seen with initiatives like the Convention on Long-Range Transboundary Air Pollution (UNECE, 1979), under which 51 countries must report to the European Monitoring and Evaluation Programme (EMEP) on their airborne emissions of 13 mandatory pollutants and 10 voluntary pollutants in full time series starting from 1990. Nevertheless, such databases are often too aggregated for their direct use in EE-MRIO models. For example only one sector for public electricity and heat production is reported in EMEP, while EXIOBASE includes 12 sectors for electricity generation and one specifically for heat. As demonstrated by Lenzen (2011) and Su and Ang (2010), a high sectoral disaggregation of both economic and environmental data increases the accuracy of environmental assessments done with input-output models. The question thus remains: how to build comprehensive national inventories of pollutant emissions with a high sectoral disaggregation and global coverage? Process-based data from life cycle inventory (LCI) databases, like ecoinvent (Weidema et al., 2013), can offer possible answers to that question. Ecoinvent thus provides a state-of-the-art coverage of 
environmental flows (i.e. pollutant emissions and resource consumption) at process level, representative of several hundreds of various technologies and countries (Wernet et al., 2016).

In this study, we therefore (i) investigate the potential of using process $\mathrm{LCl}$ data to build comprehensive inventories of pollutant emissions at national level, and (ii) discuss the relevance of inventory completeness with regard to environmental impact assessment. The production of heat and electricity, which is a key sector in several value chains (cf. Fig. B1) and for which global activity data are compiled yearly by the International Energy Agency (IEA), is used here as a case study.

\section{Materials and Methods}

\subsection{Overall methodology}

To meet the above research objectives and evaluate the influence of substance coverage at inventory level on the assessment of the environmental impacts resulting from heat and electricity generation, a 3-step methodology was developed and applied.

First, the ecoinvent-based National Energy-related Emission (ENEE) inventory was built with the intent of having the largest possible coverage of pollutant emissions, by combining national energy balances with emission factors retrieved from the unit processes modelled in ecoinvent 3.3 database (Weidema et al., 2013) and completed with other available data sources (Section 2.2). In a second step, the ENEE inventory was compared with data in reports from the United Nations Framework Convention on Climate Change (UNFCCC, 2017), EMEP official reports (EMEP/CEIP, 2017), reports from the European Pollutant Release and Transfer Register (E-PRTR; EEA 2017), and EXIOBASE national inventories (Tukker et al., 2013; Wood et al., 2015) for the main producers of heat and electricity to investigate discrepancies at substance level (Section 2.3). The characteristics of these inventories are summarized in Table 1. Finally, a comparison of the ENEE, EMEP and EXIOBASE inventories was performed at impact 
level applying Life Cycle Impact Assessment (LCIA) methodologies to evaluate the influence of their

different substance coverage on the resulting impacts across several environmental impact categories

(Section 2.4).

Table 1. Comparison of the scope and inventory methodology in EMEP official reports, the EXIOBASE inventories and the ENEE inventories, for the production of heat and electricity

\begin{tabular}{|c|c|c|c|c|c|}
\hline & ENEE Inventory & UNFCCC $^{a}$ & EMEPa & E-PRTR ${ }^{a}$ & EXIOBASE \\
\hline $\begin{array}{l}\text { Country } \\
\text { coverage }\end{array}$ & 140 countries & 30 countries & 48 countries & $\begin{array}{l}30 \text { European } \\
\text { countries }\end{array}$ & $\begin{array}{l}44 \text { countries } \\
5 \text { Rest-of-the- } \\
\text { World regions }\end{array}$ \\
\hline $\begin{array}{l}\text { Substance } \\
\text { coverage }\end{array}$ & $\begin{array}{l}231 \text { substances } \\
\text { emitted to air, } \\
\text { incl. } 51 \\
\text { radioisotopes } \\
87 \text { substances } \\
\text { emitted to } \\
\text { water, incl. } 34 \\
\text { radioisotopes }\end{array}$ & $\begin{array}{l}3 \text { substances } \\
\text { emitted to } \\
\text { air }\left(\mathrm{CO}_{2}, \mathrm{CH}_{4} \text {, }\right. \\
\left.\mathrm{N}_{2} \mathrm{O}\right)\end{array}$ & $\begin{array}{l}23 \text { substances } \\
\text { emitted to air } \\
\text { (incl. voluntary } \\
\text { reporting for } 6 \\
\text { metals) }\end{array}$ & $\begin{array}{l}25 \text { substances } \\
\text { emitted to air } \\
13 \text { substances } \\
\text { emitted to water }\end{array}$ & $\begin{array}{l}33 \text { substances } \\
\text { emitted to air }\end{array}$ \\
\hline $\begin{array}{l}\text { Time coverage } \\
\text { (annual time } \\
\text { series) }\end{array}$ & $1995-2014$ & $1995-2014$ & $\begin{array}{l}\text { 1990-2014 for } \\
\text { all pollutants } \\
\text { except for PM } \\
(2000-2014)\end{array}$ & $\begin{array}{l}2001,2004,2007- \\
2014\end{array}$ & $1995-2011$ \\
\hline $\begin{array}{l}\text { Inventory } \\
\text { methodology }\end{array}$ & $\begin{array}{l}\text { IEA }{ }^{\mathrm{a}} \text { energy } \\
\text { balances } \\
\text { Emission factors } \\
\text { from ecoinvent } \\
\text { 3.3, EMEP } \\
\text { Guidebook } \\
2016 \text {, and US } \\
\text { EPA }^{\text {a }}\end{array}$ & $\begin{array}{l}\text { 3-Tier } \\
\text { approach } \\
\text { depending } \\
\text { on the } \\
\text { availability } \\
\text { of data }\end{array}$ & $\begin{array}{l}\text { 3-Tier } \\
\text { approach } \\
\text { depending on } \\
\text { the availability } \\
\text { of data. }\end{array}$ & $\begin{array}{l}\text { Mandatory } \\
\text { reporting by } \\
\text { individual facility } \\
\text { when a capacity or } \\
\text { release threshold is } \\
\text { reached. } \\
\text { Reports may be } \\
\text { based on } \\
\text { measurements, } \\
\text { calculations, or non- } \\
\text { standardized } \\
\text { emissions. }\end{array}$ & $\begin{array}{l}\text { IEA energy } \\
\text { balances } \\
\text { Emission } \\
\text { factors from } \\
\text { the TEAM } \\
\text { model, which } \\
\text { builds on the } \\
\text { GAINS model } \\
\text { and the EMEP } \\
\text { Guidebook } \\
2009 .\end{array}$ \\
\hline $\begin{array}{l}\text { Time } \\
\text { differentiation } \\
\text { of emission } \\
\text { factors }\end{array}$ & None & $\begin{array}{l}\text { For Tier } 3 \\
\text { only }\end{array}$ & For Tier 3 only & $\begin{array}{l}\text { Depending on the } \\
\text { chosen method. }\end{array}$ & Yes. \\
\hline $\begin{array}{l}\text { Country } \\
\text { differentiation } \\
\text { of emission } \\
\text { factors }\end{array}$ & $\begin{array}{l}\text { Yes, based on } \\
\text { national } \\
\text { efficiencies and } \\
\text { typical fuel } \\
\text { properties. }\end{array}$ & $\begin{array}{l}\text { For Tiers } 2 \\
\text { and } 3 \text { only. }\end{array}$ & $\begin{array}{l}\text { For Tiers } 2 \text { and } \\
3 \text { only }\end{array}$ & $\begin{array}{l}\text { Depending on the } \\
\text { chosen method. }\end{array}$ & Yes. \\
\hline Consistency & $\begin{array}{l}\text { Fully consistent } \\
\text { across countries } \\
\text { and years. }\end{array}$ & $\begin{array}{l}\text { Consistent } \\
\text { across } \\
\text { countries } \\
\text { and years }\end{array}$ & $\begin{array}{l}\text { Potentially } \\
\text { inconsistent } \\
\text { across } \\
\text { countries and }\end{array}$ & $\begin{array}{l}\text { Potentially } \\
\text { inconsistent across } \\
\text { countries and years } \\
\text { (change in }\end{array}$ & $\begin{array}{l}\text { Fully consistent } \\
\text { across } \\
\text { countries and } \\
\text { years. }\end{array}$ \\
\hline
\end{tabular}




\begin{tabular}{|l|l|l|l|l|}
\hline & $\begin{array}{l}\text { years (change } \\
\text { in substance } \\
\text { coverage) }\end{array}$ & $\begin{array}{l}\text { completeness, } \\
\text { methodology, } \\
\text { and/or substance } \\
\text { coverage) }\end{array}$ & \\
\hline
\end{tabular}

${ }^{a}$ EMEP: European Monitoring and Evaluation Programme; ENEE Inventory: Ecoinvent-based National Energy-related Emission Inventory; IEA: International Energy Administration; US EPA: United States Environmental Protection Agency; UNFCCC: United Nations Framework Convention on Climate Change; E-PRTR: European Pollutant Release and Transfer Register

\subsection{Building the ENEE inventory}

The $\mathrm{LCl}$ database ecoinvent 3.3 includes inventories of emission, energy and material flows for heat and electricity production processes differentiated into major technologies within fossils-based, renewables and nuclear power generation (Frischknecht, 2005; Laurent and Espinosa, 2015; Weidema et al., 2013). These inventories are compiled by industries and/or experts and undergo a review process before being published as part of the official ecoinvent database.

Emission factors (in kg or kBq emitted substance per generated kWh electricity or MJ heat) for direct airborne and waterborne pollutants (i.e. releases to air and water, respectively) were retrieved for over 30 technologies of heat and electricity production (see Supporting information B for more information regarding the temporal, geographical and technological representativeness of ecoinvent processes). They cover a range of greenhouse gases, organics and inorganic chemicals, including radioisotopes. When possible, country-specific data on the fuel characteristics, as well as on the installation rates and efficiencies of pollution control, were taken into account in the development of ecoinvent emission factors for substances such as NOx, SOx, or trace elements (Dones et al., 2007; Treyer and Bauer, 2016). Even though ecoinvent supports modelling of the emissions from the whole life cycle of the electricity generation, the retrieved emission factors only capture the direct airborne emissions from the power plants and do not cover the extraction, refinement and transport of the fuel material nor the handling of the production waste, which can be attributed to other sectors. 
These process-specific emission inventories can then be upscaled to the national level by multiplying them with national electricity and heat production statistics retrieved from the IEA for 140 countries over the period 1995-2014 (IEA, 2016). The direct use of ecoinvent processes presents however two weaknesses: (i) the substance coverage for a given production technology is not fully harmonized across countries, and (ii) some process inventories appear to omit some emissions of toxic substances, for which emission factors have been documented in the literature. Each of these two shortcomings is shortly described below.

Despite LCls being generally consistent across countries, two groups of countries can indeed be identified with a different level of substance coverage for electricity production from hard coal (56 or 84 substances) and conventional gas (23 or 31 substances). In ecoinvent 2.2, which was used as starting point for building version 3, the dataset for the United States had a larger substance coverage than the datasets for the other countries. In ecoinvent 3.3, datasets have been created for new countries, where the emission flows were extrapolated from the production-weighted averages of all the existing ecoinvent 2.2 datasets including the US one, thus resulting in the larger substance coverage. To solve this first issue and harmonize the substance coverage across all countries for a given production process, the average emissions per fuel input were used to extrapolate the missing emission factors in other countries (in $\mathrm{kg} / \mathrm{kWh}$ or $\mathrm{kg} / \mathrm{MJ})$, thus assuming an average pollutant removal.

Regarding the second issue, it was for example found that the ecoinvent processes for electricity generation from natural gas do not document any airborne emissions of copper or zinc, whereas literature tends to indicate that such pollutant releases do take place for this production technology (Nielsen et al., 2013; Trozzi et al., 2010). Similarly, ecoinvent processes do not show any emission of hexachlorobenzene from coal combustion, whereas the EMEP/EEA Guidebook 2016 does (Nielsen et al., 2016). Furthermore, except for benzo(a)pyrene and acenaphthene in some processes, polycyclic aromatic hydrocarbons (PAHs) are commonly reported as a group in ecoinvent. This may be an issue for 
assessing the resulting environmental impact since this group includes more than 100 individual substances with different physicochemical properties, out of which 15 are known to be carcinogenic (US HHS, 2016). As a result, the environmental impact of the group of PAHs is hard to characterize, and emission inventories of the individual substances are preferred. To fill these gaps and expand the substance coverage for several production technologies, uncontrolled emission factors were retrieved from the EMEP/EEA Guidebook 2016 (Nielsen et al., 2016), the United States Environmental Protection Agency (US EPA) (US EPA, 2010, 2003, 1998a, 1998b, 1998c), and Wenborn et al. (1999). While emission factors from the US EPA represent measurement data for multiple pollutants from the combustion of coal, lignite, gas, oil and wood in several facilities in the 90s, they are here assumed to be representative for these fuels in all countries in the period 1995-2014. Combining these emission factors with countryand technology-specific data about the fuel inputs required for the production of heat and electricity (as documented by ecoinvent), new country-specific emission factors (expressed in $\mathrm{kg}$ or kBq of pollutant emissions per kWh of electricity or MJ heat) were calculated and introduced in the ecoinvent unit process inventories.

The product of the completed process-based emission factors and national production volumes of heat and electricity (IEA, 2016) provides national estimates for the releases of 231 airborne emissions and 87 waterborne emissions in 1995-2014, including 51 and 34 radioisotopes, respectively (cf. Table 1).

\subsection{Comparison with publicly available inventories of pollutant emissions}

To investigate the accuracy of the ENEE inventory, estimates were compared at substance level with UNFCCC reports (UNFCCC, 2017), EMEP official reports (EMEP/CEIP, 2017), E-PRTR reports (EEA, 2017), and EXIOBASE inventories (Tukker et al., 2013; Wood et al., 2015). These inventories have the advantage of having large substance, country and/or year coverage, thus allowing identifying potential methodological discrepancies. 


\subsubsection{UNFCCC reports}

Parties to the Kyoto Protocol must annually report their national greenhouse gas emissions to the UNFCCC (UNFCCC, 2017). The reports for the sector 1.A.1.a "Public heat and electricity production" include emissions of $\mathrm{CO}_{2}, \mathrm{CH}_{4}$ and $\mathrm{N}_{2} \mathrm{O}$ from fuel combustion in thermal power plants in 30 countries. They were compiled following the IPCC guidelines, which recommend a 3-tier approach depending on the availability of data (i.e. using respectively average, country-specific, or technology-specific emission factors) (Gómez et al., 2006). The UNFCCC reports were compared with the ENEE estimates for the main producers of heat and electricity generation in the corresponding countries over 1995-2014.

\subsubsection{EMEP official reports}

National emissions of pollutants in the sector "1.A.1.a Public electricity and heat production" were retrieved from the official EMEP reports of 48 countries in 1995-2014, covering emissions from combustion plants as main producers (EMEP/CEIP, 2017; Nielsen et al., 2016). EMEP recommends a tiered approach to quantify the national releases of pollutants, based on the data availability in the country. In the absence of measurements or specific information on the technologies used (Tiers 2 and 3), the EMEP/EEA Guidebook provides Tier 1 emission factors for 6 types of fuel, i.e. hard coal, brown coal, gaseous fuels, heavy fuel oil, light oil and biomass (Nielsen et al., 2016). To accommodate better monitoring data and changes in technology performance, the guidebook was updated in 2009,2013 , and 2016 with a few important changes between updates: the emission factor for copper from the combustion of gaseous fuels thus decreased by more than 3 orders of magnitude between the 2009 and 2016 editions (Nielsen et al., 2016; Trozzi et al., 2010). The fact that some countries use Tier 1 emission factors and others use more detailed and specific data is a source of inconsistent national reporting across countries and years. In addition, a review of the pollutant reporting pinpointed its incompleteness, with only 32 parties out of 45 having provided the full time series $1990-2014$ for the main pollutant emissions (Mareckova et al., 2016). 


\subsubsection{E-PRTR reports}

Industrial facilities in Europe need to report their emissions of pollutants to the E-PRTR when the capacity of the facility or the level of pollutant release exceeds a threshold (EC, 2006). For example, thermal power stations need to report their emissions if their heat input is above $50 \mathrm{MW}$. While the emission thresholds were set so that the reporting covers $90 \%$ of the actual releases, some studies tend to indicate that the thresholds are too high or that the reporting is incomplete for some substances and environmental compartments (Manfred et al., 2012). The E-PRTR reports from facilities falling under the activity "Production of electricity" (sectors 35.11 and 40.11 in the classifications NACE1 and NACE2, respectively) were retrieved (EEA, 2017), and aggregated at national level to be compared with the ENEE inventory estimates for the main producers of electricity. The comparison covers 25 airborne emissions and 13 waterborne emissions in 30 European countries in the years 2001, 2004, 2007-2014.

\subsubsection{EXIOBASE inventories}

Developed under European Commission research funding, the global EE-MRIO model EXIOBASE (version 3.4) differentiates 12 industries for electricity production and 1 industry for heat generation, each with an inventory of 33 airborne emissions in 44 countries and 5 complementary "rest of world" (RoW) regions over the period 1995-2011 (Stadler et al., 2018; Tukker et al., 2013; Wood et al., 2015).

In EXIOBASE, direct emissions from heat and electricity generation are quantified with the TNO Emission Assessment Model (TEAM model), based on fuel consumption statistics from the IEA energy balances, and country- and time-specific emission factors expressed as kg of substance emitted per MJ of fuel input (Kuenen et al., 2015; Stadler et al., 2018). The TEAM model builds on the estimates of airborne emissions given by the GAINS model for greenhouse gases, nitrogen oxides, sulfur oxides, particulate matter and ammonia (IIASA, 2018), filling the gaps in the time-series by linear interpolation. Emissions of heavy metals and persistent organic pollutants are then derived from PM10 by using as a 
proxy the distribution of the pollutant releases proposed by the Tier 1 emission factors in the EMEP/EEA Guidebook 2009 (Trozzi et al., 2010).

\subsection{Impact assessment}

Through their inherent physicochemical and toxicological properties, different substances have different potential to contribute to a variety of environmental impacts. By modelling the cause-effect chains of individual substances $s$ in the environment, LCIA methods translate substance emissions $Q_{s}$ into potential impacts $I_{i}$ on ecosystems and human health using characterization factors $C F_{s, i}$ representing their potency (ISO, 2006), as defined in Eq.1 for a given environmental impact category $i$.

$I_{i}=\sum_{s}\left(Q_{s} \times C F_{i, s}\right)$

Here, the LCIA methodologies are applied to the ENEE inventories, the EXIOBASE inventories, and the EMEP reports. As the UNFCCC reports only cover emissions that are relevant for climate change (i.e. greenhouse gas), they were excluded from the analysis at impact level. Similarly, no comparison at impact level was performed with the E-PRTR reports due to the inconsistent substance coverage of the reporting across countries, which would hinder any interpretation (see Section 3.2.3).

Table 2 gives a summary of the impact categories selected in this study, together with the chosen LCIA methods. The impacts of chemical releases on human health and freshwater ecosystems (termed 'human toxicity' and 'freshwater toxicity', respectively) were quantified using the consensus model USEtox v.2.02. Ecoinvent processes for heat and electricity generation indicate that the airborne emissions occur in a rural or urban environment depending on the production technology ("low. pop." or "high. pop."), this choice is however not justified (Bauer, 2017). It was thus assumed that all airborne emissions were released to continental rural air (defined as local air in rural areas, as opposed to continental urban air) (Hauschild et al., 2008; Rosenbaum et al., 2008). In addition, the LCIA methodology ReCiPe2016 was used to characterize the environmental impacts of heat and electricity 
production on climate change, ionizing radiation, stratospheric ozone depletion, particulate matter formation, terrestrial acidification, and photochemical ozone formation impacting human health (Huijbregts et al., 2017). Despite being available for particulate matter formation, terrestrial acidification, photochemical ozone formation, and freshwater eutrophication, country-specific characterization factors were not considered here, as the focus of the study is primarily on comparing inventory completeness and its general influence on impact scores, rather than on spatial differentiation of the impact assessment results. Furthermore, USEtox does not include spatially-differentiated characterization factors for human toxicity and freshwater ecotoxicity, impact categories for which it is expected to find the largest difference in term of substance coverage across inventories.

Table 2. Selected impact categories and associated LCIA methodologies

\begin{tabular}{|c|c|c|}
\hline Impact category & LCIA method [Ref] & Impact score unit \\
\hline Climate change & Huijbregts et al. 2017 & $\mathrm{Kg} \mathrm{CO}_{2}$-eq \\
\hline Ionizing radiation & Huijbregts et al. 2017 & kBq Co-60 to air eq \\
\hline Stratospheric ozone depletion & Huijbregts et al. 2017 & kg CFC11-eq \\
\hline Particulate matter formation & Huijbregts et al. 2017 & kg PM2.5-eq \\
\hline Terrestrial acidification & Huijbregts et al. 2017 & $\mathrm{~kg} \mathrm{SO}_{2}-\mathrm{eq}$ \\
\hline $\begin{array}{l}\text { Photochemical ozone formation (impacting } \\
\text { human health) }\end{array}$ & Huijbregts et al. 2017 & $\mathrm{~kg} \mathrm{NO}_{x}$-eq \\
\hline Freshwater eutrophication & Huijbregts et al. 2017 & Kg P-eq to freshwater \\
\hline Human toxicity (cancer and non-cancer effects) & $\begin{array}{l}\text { Rosenbaum et al. } 2008 \text {; } \\
\text { Hauschild et al. } 2008\end{array}$ & $\mathrm{CTU}_{\mathrm{h}}{ }^{\mathrm{a}}$ \\
\hline Freshwater toxicity & $\begin{array}{l}\text { Rosenbaum et al. 2008; } \\
\text { Hauschild et al. } 2008\end{array}$ & $\mathrm{CTU}_{\mathrm{e}}^{\mathrm{a}}$ \\
\hline
\end{tabular}

${ }^{\mathrm{a}} \mathrm{CTU}_{\mathrm{h}}=$ Comparative toxic unit (human health), $\mathrm{CTU}$ = Comparative toxic unit (ecosystem)

\section{Results}

\subsection{Newly-developed ENEE inventory}

The newly-developed ENEE inventory (see Section 2.2) covers 231 substances emitted to air and 87 substances emitted to water (incl. 51 and 34 radioisotopes, respectively), differentiated into 140 countries over the period 1995-2014. The complete national inventories are available in Supporting Information 1. Fully consistent across countries and years, the ENEE inventory is believed to be currently 
the most comprehensive data set for direct emissions from the energy sector in terms of substance coverage. As such, it helps fully capture the impact of heat and electricity generation across all environmental impact categories when performing LCAs at macro-level. Alone, it is however not suited to support full environmental impact assessment of various energy technologies as it focuses only on direct emissions from power plants and excludes the rest of the systems' life cycles (e.g. extraction of raw materials and fuels, refining, end-of-life, etc.).

The quantification of the uncertainty in the inventory estimates is hindered by the low availability of uncertainty data on the IEA activity rates and the emission factors. For example, while the ecoinvent database includes some estimations of uncertainties based on an assumed lognormal distribution and a semi-quantitative step-wise approach applied to different groups of emissions (Weidema et al., 2013), the US EPA only provides a qualitative and non-explicit ranking of the emission factors. A full quantitative uncertainty assessment is thus not possible at the moment, and the ENEE inventory is limited to the provision of best estimates with a qualitative discussion of the uncertainties, as summarized in the following. A higher uncertainty in the inventory results is expected for pollutants, which, unlike for example $\mathrm{CO}_{2}$, are effectively removed by abatement technologies, since the applied methodology does not include time-dependent emission factors. In reality, the implementation of lowNOx burners, bag filters, electrostatic precipitators, etc. affects the emission intensities of several substances, each to a different extent (Meij and te Winkel, 2007; Urashima and Chang, 2000; Wang et al., 2014). In addition to this limitation, a higher uncertainty is expected for the inventories of substances that rely on emission factors retrieved from the US EPA, due to the limited time and geographical representativeness of the emission data. Similarly, there is a high uncertainty in the inventories for non-European countries as emission factors in the ecoinvent database are mainly derived from European data. Further research should address these aspects to increase the inventory accuracy (see Section 4.1). 


\subsection{Comparison with other inventories}

\subsubsection{Comparison with UNFCCC reports}

Overall, a very good correlation was obtained between the ENEE estimates and the UNFCCC reports for $\mathrm{CO}_{2}$ (Fig. 1). This first finding for a non-controlled chemical (i.e. minor influence of fuel and power plant characteristics) attests that the methodology used to upscale process-based LCI to retrieve national emission inventories is coherent, and properly covers all main technologies, thus supporting the credibility and applicability of the approach. A higher discrepancy is observed for $\mathrm{CH}_{4}$ and $\mathrm{N}_{2} \mathrm{O}$, which may indicate that individual authorities may have had access to additional primary data specific to the technology or fuel used in the country.
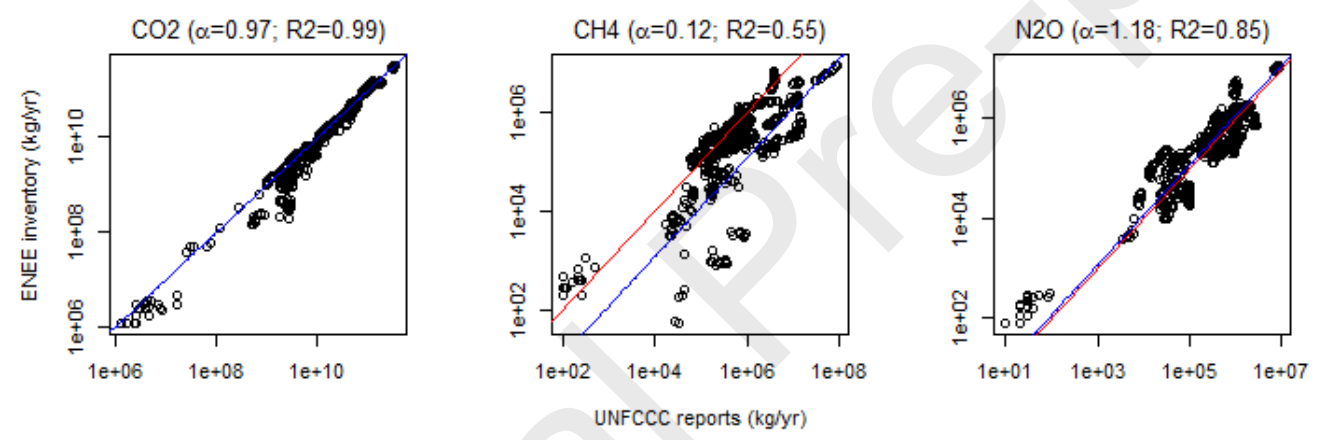

Figure 1. ENEE inventory plotted against UNFCCC reports (country-and year-specific data). The red line indicates an ideal regression (i.e. $y=x$, agreement between the two inventories); the blue line indicates the actual linear regression. Note the logarithmic scale on both axis.

\subsubsection{Comparison with EMEP official reports}

A rather large dispersion of the ratios between the ENEE inventories and EMEP official reports is observed for most pollutants, with distributions typically ranging several orders of magnitude, thus indicating that there is a low correlation between the two data sets (Fig.2). This is particularly true for all persistent organic pollutants (POPs), for which the ENEE inventory provides estimates that seem systematically lower than the EMEP reports (e.g. the geometric mean of the ratios is 0.02 for benzo(b)fluoranthene, $B(b) f$ in Fig. 2). These substances are also the least reported ones, with for example 385 reports of indeno(1,2,3-cd)pyrene available over the period and countries considered, 
against 700 for nitrogen oxides. This lack of consistent substance coverage across countries may be due to the reporting guidelines (e.g. some metals are based on a voluntary reporting only), or to difficulties in quantifying the actual releases. It also means that any comparison of the countries' performances at impact level should be handled extremely carefully as the substance coverage may differ from one nation to another.

Clusters of countries and potential outliers can be identified (see scatterplots in Figures B2-B4), thus highlighting that the use of methodologies is not fully harmonized across countries: while some of the official reports may be based on measurements or more technology-specific data, others are built on generic emission factors derived from the EMEP/EEA guidebooks. Except from a few updates, these are essentially based on measurements realized in the US in the 1990s, i.e. with a limited geographical and temporal representativeness. The consistency across emission reports from different sources is also substance-specific, with reasons for potential discrepancies that can vary considerably. For example, there is no recommended emission factor to estimate the releases of ammonia from public heat and electricity production according to the EMEP/EEA guidebooks. Consequently, all the EMEP reports for this substance were built with country-specific methodologies thus explaining the low correlation with the ENEE inventory (see Fig. 2).

Such comparison as in Figure 2 also enables identification of potential outliers in emission reports. For example, the Estonian EMEP official reports show emissions of selenium that are ca. 5 orders of magnitude lower than those in the ENEE inventory (see Fig. B4), whereas, on average, estimates for selenium from EMEP official reports are only 2.2 times lower than those from the ENEE inventory across all countries. The Estonian EMEP reports also feature one of the lowest estimates in Europe for selenium, despite its electricity production mix being dominated by coal combustion. Such 
outliers are likely to stem from reporting errors, which should be mitigated by relevant stakeholders (see Section 4.1).

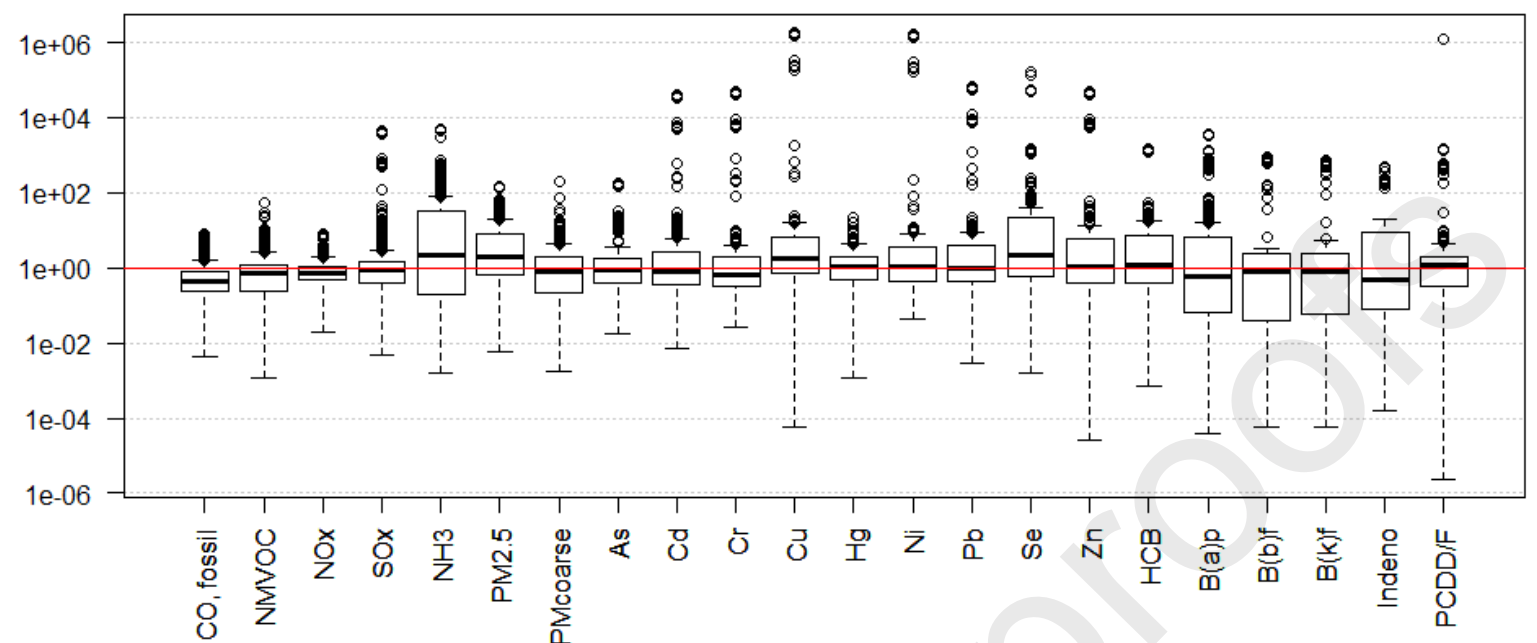

Figure 2. Boxplot of the ratios of the ENEE inventory estimates divided by the EMEP official reports (country-and year-specific data). The red line indicates a ratio equal to 1 (= agreement between the two inventories). Box plots indicate 25-75 percentile (respectively Q1 and Q3), with the midline indicating the median, while whiskers indicate the minima-maxima excluding outliers. Outliers (dots) are defined as points higher than $Q 3+1.5 I Q$ or lower than $Q 1-1.5 I Q$, with $I Q$ being the inter-quartile range IQ=Q3$Q 1$. Note the logarithmic scale on the $y$-axis. $H C B=H$ exachlorobenzene, $B(a) p=$ benzo(a)pyrene, $B(b) f=b e n z o(b) f l u o r a n t h e n e$, $B(k) f=$ benzo $(k)$ fluoranthene, Indeno = indeno $(1,2,3-c d)$ pyrene, $P C D D / F=$ Dioxins and furans.

\subsubsection{Comparison with E-PRTR reports}

Although the E-PRTR reports constitute primary data provided by the industrial facilities

themselves, their completeness can be questioned due to the existence of reporting thresholds or gaps in the missing reports. There is for example no report of carbon dioxide or metal emissions to air from the sector "Public electricity production" in Poland or Latvia. Likewise, substances like DEHP, tetrachloromethane (TCM) and trichloroethene (TCE) were reported by only one country each, and only for one or two years (hence the absence of visible boxplots for those substances in Fig.3a). The gaps may even be more important for waterborne emissions, for which facility reports are only available for 23 out of the 30 countries subject to reporting.

For most airborne emissions, the ENEE estimates generally tend to be higher than those in the E-PRTR reports (median ratio $>1$, see Fig. 3a), which may be an effect of the reporting thresholds in the E-PTRT. A large dispersion can nevertheless be observed for nearly all substances which may be partially 
explained by the fact that, in accordance with the E-PRTR Regulation, operators are obliged to submit data on emissions from the whole facility, thus including releases from fuel combustion as well as other activities (e.g. transportation or facility maintenance). A particular pattern is observed for the emissions of chlorine and fluorine to air, for which the ENEE inventory provides estimates that are on average two orders of magnitude lower than in the E-PRTR reports. In the ENEE inventory, electricity production from wood combustion is the only technology that includes emission factors for these substances. This analysis may suggest that these emission factors are underestimated, or that emissions of chlorine and fluorine may occur with other production technologies.

Despite the existence of the reporting thresholds in the E-PRTR, the ENEE inventory provides generally lower estimates than the E-PRTR reports for waterborne emissions, reaching more than 4 orders of magnitude difference in some countries for most pollutants. It appears hence likely that the emissions to water are underestimated in the ENEE inventory. For example, in ecoinvent, direct emissions to water are only included for electricity production from oil and waste combustion, as well as nuclear power. The absence of direct waterborne emissions from the combustion of other fuels such as coal (Córdoba et al., 2011; Gingerich et al., 2017; Mokhtar et al., 2014) constitutes a potential data gap in ecoinvent, and should be further investigated. 
(a) Airborne emissions

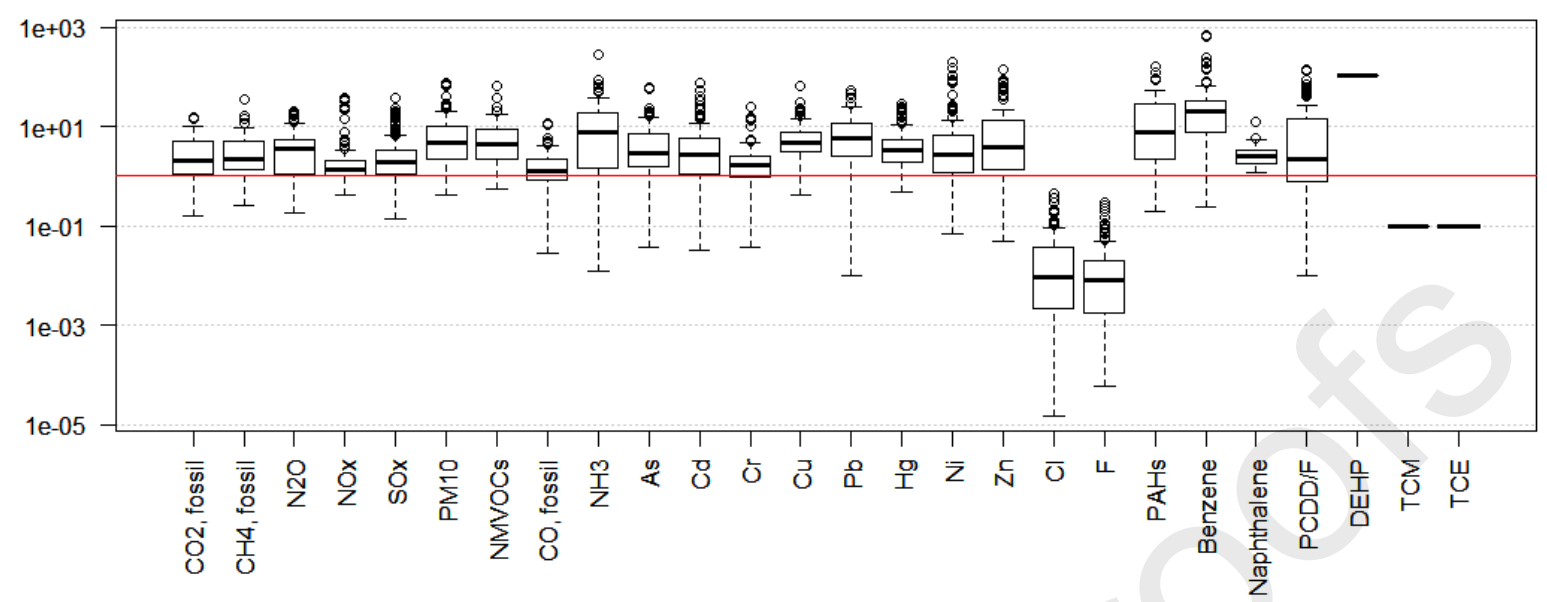

(b) Waterborne emissions

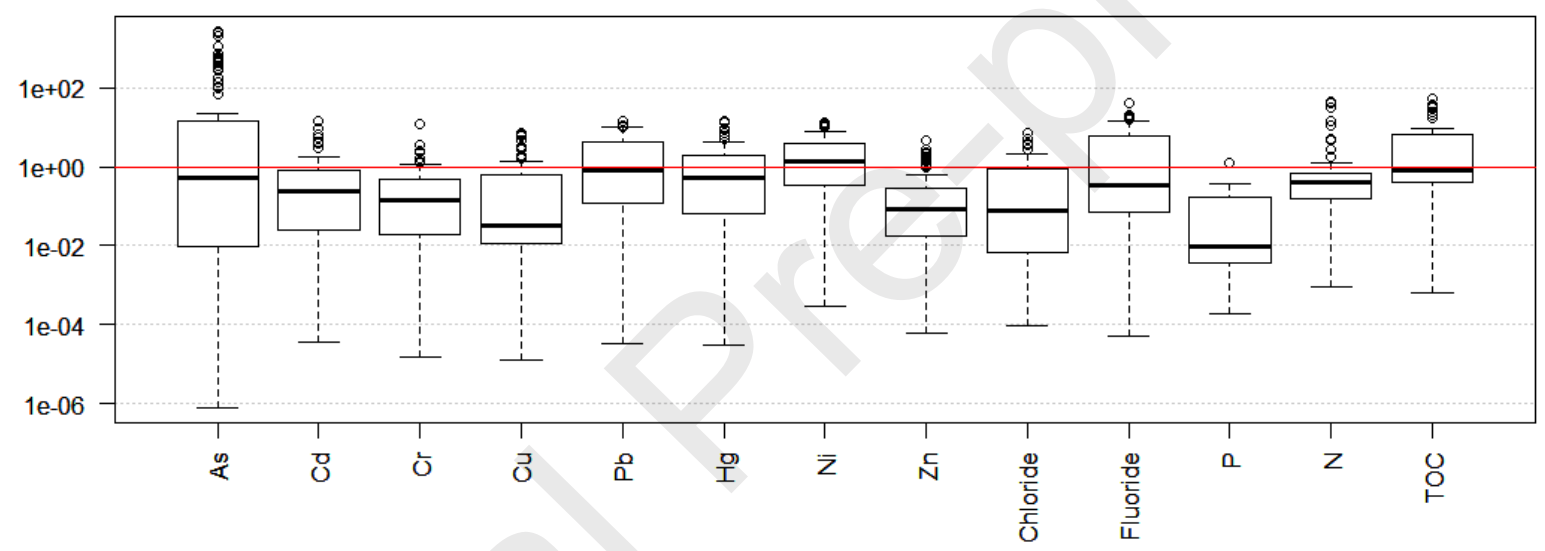

Figure 3. Ratios of ENEE inventory estimates divided by the E-PRTR reports for (a) airborne emissions and (b) waterborne emissions from electricity production (country-and year-specific data). The red line indicates a ratio equal to 1 (= agreement between the two inventories). Box plots indicate 25-75 percentile (respectively Q1 and Q3), with the midline indicating the median, while whiskers indicate the minima-maxima excluding outliers. Outliers (dots) are defined as points higher than $Q 3+1.5 I Q$ or lower than $Q 1-1.5 I Q$, with IQ being the inter-quartile range IQ=Q3-Q1. Note the logarithmic scale on the $y$-axis. $P C D D / F=$ Dioxins and furans, TCM = Tetrachloromethane, $T C E=$ Trichloroethene, $T O C=$ Total organic carbon.

\subsubsection{Comparison with EXIOBASE inventories}

The ENEE and EXIOBASE inventories show a good agreement for $\mathrm{CO}_{2}$ emissions, with the distribution of the ratios having a geometric mean of 0.94 and a geometric standard deviation (GSD) of 1.34 (Fig. 4, Table B6). A larger distribution of the ratios is observed for metals (average GSD of 3.9) and persistent organic pollutants (average GSD of 8.3). Emissions of benzo(b)fluoranthene and benzo(k)fluoranthene from the combustion of hard coal, brown coal and heavy fuel oil are "not estimated" in the EMEP/EEA Guidebook 2009, which was used to derive the emissions factors in 
EXIOBASE. However, a set of emission factors are recommended in the updated 2016 version of the guidebook, which was used to build the ENEE inventory. It is thus likely that the releases are underestimated in EXIOBASE for these two PAHs, thus explaining the high ratios observed in Fig. 4.

Further analysis by fuel category reveals that the ENEE inventory provides estimates of copper and zinc emissions that are on average 3 orders of magnitude lower than those in the EXIOBASE inventory for the production of electricity by gas (Fig. B10). For this production technology, the emission factors used in the ENEE inventory (derived from the EMEP/EEA Guidebook 2016) are indeed nearly a thousand times lower than the ones recommended in the EMEP/EEA Guidebook 2009, which was used as starting data for deriving EXIOBASE emission factors. Similarly, to estimate releases of hexachlorobenzene from the combustion of hard coal, the emission factor recommended by the EMEP/EEA guidebook increased by a factor 10 between the 2009 and 2016 versions. These observations underline the fact that the primary data used to derive emission factors in EXIOBASE may be outdated.

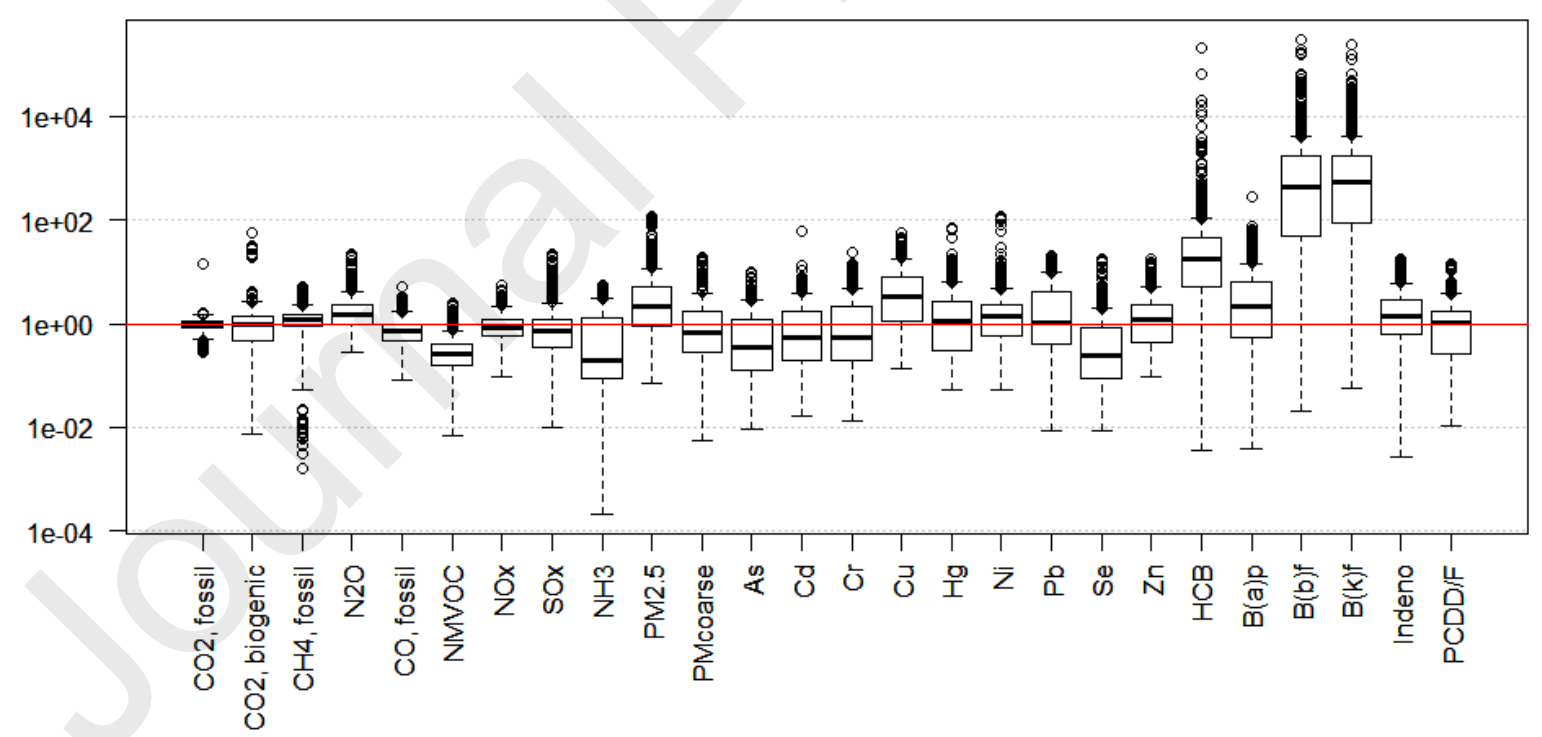

Figure 4. Boxplot of the ratios of the ENEE inventory estimates divided by the EXIOBASE inventory for 44 countries in 1995-2011 (country-and year-specific data). The red line indicates a ratio equal to 1 (= agreement between the two inventories). Box plots indicate 25-75 percentile (respectively Q1 and Q3), with the midline indicating the median, while whiskers indicate the minimamaxima excluding outliers. Outliers (dots) are defined as points higher than Q3+1.5IQ or lower than Q1-1.5IQ, with IQ being the inter-quartile range $I Q=Q 3-Q 1$. Note the logarithmic scale on the $y$-axis. $H C B=$ Hexachlorobenzene, $B(a) p=b e n z o(a) p y r e n e$, $B(b) f=$ benzo(b)fluoranthene, $B(k) f=$ benzo $(k)$ fluoranthene, Indeno = indeno $(1,2,3-c d)$ pyrene 


\subsection{Influence of substance coverage on impact assessment}

Under the assumption that the ENEE estimates and the LCIA characterization factors are accurate, Fig. 5 illustrates the average contribution of the substances being covered by EMEP reports, EXIOBASE and the ENEE inventories to the impact scores obtained with the ENEE inventory for each environmental impact category. Overall, this pattern is not expected to change with the use of countryspecific characterization factors from ReCiPe2016 (Huijbregts et al., 2017), as those are only available for impact categories where either $100 \%$ or $0 \%$ of the relevant substances are covered by the EXIOBASE inventory or EMEP reports (i.e. particulate matter formation, terrestrial acidification, photochemical Ozone formation and freshwater eutrophication). Figure 5 shows that the EMEP reports cannot be used to assess impacts such as climate change or stratospheric ozone depletion because substances relevant for these categories are not included in the scope of this reporting. Similarly, emissions of radioisotopes are solely covered by the ENEE inventory, which is here the only one that can be used to assess the ionizing radiation potential from heat and electricity generation. EXIOBASE appears to cover all the substances relevant for climate change, particulate matter formation, photochemical ozone formation (human damage) and terrestrial acidification. Yet, on average, $37 \%$ of the impact score obtained for a country for freshwater ecotoxicity is due to substances that are not included in EXIOBASE. Depending on the energy mix of the country, this share varies from 4\% (Montenegro) to 96\% (Czech Republic) (data not shown).

At global level, airborne emissions of aluminium and vanadium, and waterborne emissions of copper and iron represent $\mathbf{2 9 . 4 \%}$ of the impact score for freshwater ecotoxicity from public heat and electricity generation (direct emissions only). For human toxicity (cancer effects), differentiating the speciation of chromium between $\mathrm{Cr}(\mathrm{III})$ and $\mathrm{Cr}(\mathrm{VI})$ is of high importance as the latter - more toxic - may contribute up to $14.4 \%$ of the global impact score (emissions to air and water aggregated). Table B9 
gives an overview of the top-contributing substances for each environmental impact category at global level, as calculated with the ENEE inventory.

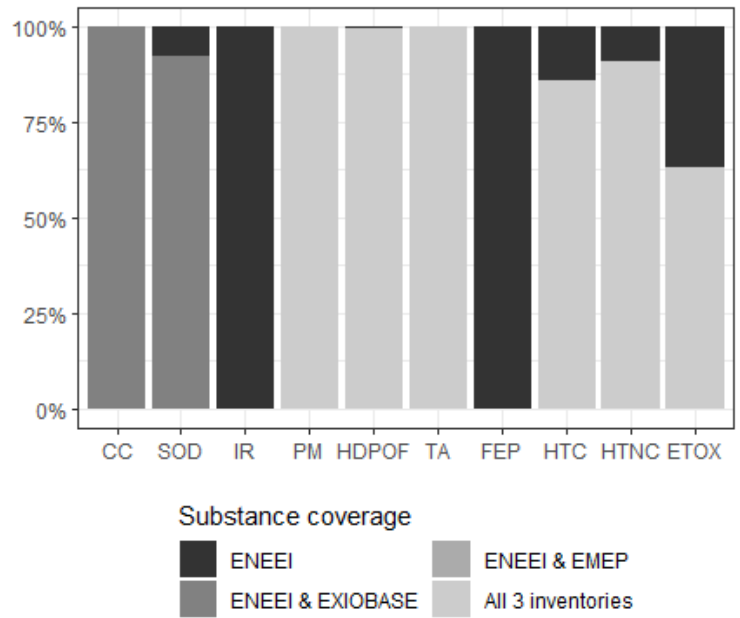

Figure 5. Contribution of substance categories to the impact scores obtained with the ENEE inventory. CC: Climate change, SOD: Stratospheric ozone depletion, IR: lonizing radiation; PM: Particulate matter formation, HDPOF: Human damage photochemical oxidant formation, TA: Terrestrial acidification, FEP: freshwater eutrophication; HTC: Human toxicity (cancer effects), HTNC: Human toxicity (non-cancer effects), ETOX: Freshwater ecotoxicity.

The combination of the differences in substance coverage and the differences in emission values results in large differences between the impact scores obtained with the ENEE inventory and the EXIOBASE inventory (Fig. 6). For impact categories such as climate change, stratospheric ozone depletion, particulate matter formation, photochemical ozone formation or terrestrial acidification, the discrepancies at impact level are primarily due to the uncertainty in the emission estimates as both inventories cover the most relevant substances. For toxicity-related impact categories, while the comprehensiveness of the substance coverage appears to have overall a lower influence on the assessment results than the actual emission values, it does affect the validity of the results for some countries. As an extreme case, the difference between the human toxicity impact scores obtained for Luxembourg in 2011 with the two inventories jumps from a factor of 40 when a similar substance coverage is used (Fig. 6a), to a factor of 1250 when the full substance coverage of the ENEE inventory is used (Fig. 6b). 
(a) Same substance coverage

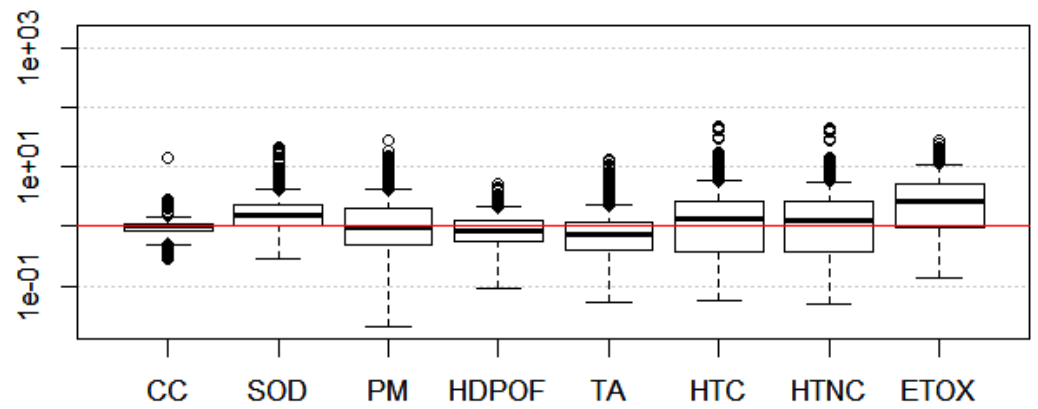

(b) Full substance coverage

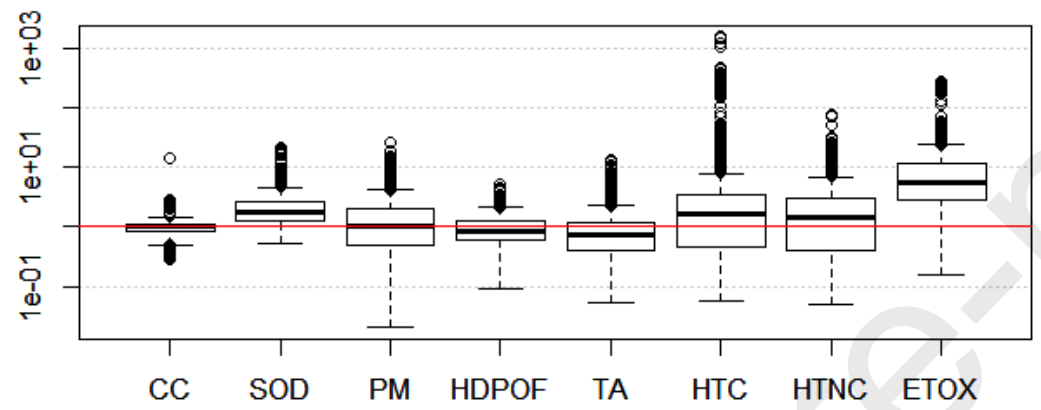

Figure 6. Impact scores obtained for the ENEE inventory divided by the impact scores for the EXIOBASE inventory for 44 countries in 1995-2011 with (a) an identical substance coverage and (b) a full substance coverage in both inventories (= ENEE inventory being more comprehensive than EXIOBASE). Red line indicates equal impact results. Box plots indicate 25-75 percentile (respectively Q1 and Q3), while whiskers indicate the minima-maxima excluding outliers. Outliers (dots) are defined as points higher than $Q 3+1.5 I Q$ or lower than $Q 1-1.5 I Q$, with IQ being the inter-quartile range IQ=Q3-Q1. CC: Climate change, SOD: Stratospheric ozone depletion, PM: Particulate matter formation, HDPOF: Human damage photochemical oxidant formation, TA: Terrestrial acidification, HTC: Human toxicity (cancer effects), HTNC: Human toxicity (non-cancer effects), ETOX: Freshwater ecotoxicity.

\section{Discussion}

\subsection{Limitations and research needs for improving the ENEE inventories}

\subsubsection{Temporal differentiation}

Because the ENEE inventory builds on historic activity data on heat and electricity production, they allow analyzing the effect of a change in the energy mix of a given country (such as a switch from fossil fuel combustion towards more renewable energy) on the resulting national emissions. However, technological improvements for a given source (e.g. the development of combined cycle power plants over conventional simple-cycle power plants for the combustion of natural gas) are not captured in the 
ENEE inventory due to the lack of country- and year- specific information on their respective level of implementation (cf. SI B). The influence of this modelling simplification appears however to be minimal, since the ENEE inventory of $\mathrm{CO}_{2}$ emissions shows a good agreement with the UNFCCC reports (cf. Section 3.2.1).

Finally, the emission factors are constant over time, meaning that improvements in pollution control technologies or changes in fuel properties are currently not accounted for in the ENEE inventory. The efficiency of abatement technologies is substance-specific and depends among other things on the type of boiler installed in thermal facilities and the fuel properties (e.g. ash content) (Meij and te Winkel, 2007; Mokhtar et al., 2014; Urashima and Chang, 2000; Wang et al., 2014). In some situations, a decrease in the emissions of a given substance can lead to an increase in the emissions of another substance through chemical transformation. Mokhtar et al. (2014) have for example demonstrated that flue gas desulfurization has the potential to increase emissions of mercury or chlorine depending on the sorbent used (limestone or seawater) (Mokhtar et al., 2014). For some substances, models have been developed to take into account the level of implementation and influence of some abatement technologies such as electrostatic precipitators, bag filters, selective catalytic reduction, flue gas desulfurization, etc. It is for example the case of the GPED database (Tong et al., 2018) or the GAINS model (IIASA, 2018), which is used as input in EXIOBASE for the emissions of greenhouse gases, nitrogen oxides, sulfur oxides and particulate matter. In parallel, the developers of EXIOBASE assumed that metals and persistent organic pollutants were affected by abatement technologies in the same proportions than PM10, and thus derived emission intensities from modelled emissions of PM10 (Stadler et al., 2018). This method has however not yet been verified nor validated, and although it may be meaningful for some combinations of treatment technologies and substances (e.g. heavy metals removal from electrostatic precipitator), this assumption may not hold true for more volatile substances such as some organic compounds or mercury (Kuenen, 2018). For example, in coal-firing power plants, 
electrostatic precipitators remove $99.8 \%$ of PM but only $49.6 \%$ of mercury particles, while emissions of dioxins and furans depend mainly on the level of completion of the combustion reaction (Meij and te Winkel, 2007). Yet, to date and to the knowledge of the authors, no publicly available database or literature document the level of implementation of the various pollution control technologies in time series by country, nor their removal efficiencies for all the 231 substances considered in this study.

Though ecoinvent database already includes country-specific emission factors that account for pollution control for some substances (e.g. NOx, SOx, trace elements), defining time-differentiated emission factors remains critical to capture the effects on all pollutant emission intensities from the abatement technologies implemented in the last years. It calls for updated measurements with transparent documentation regarding the abatements methods used, as well as the characteristics of the fuel and the power plant. Experiments investigating the effect of some pollution control technologies on the emissions of a large range of substances would additionally help evaluate the uncertainty surrounding the use of particulate matter releases as a proxy for the rest (e.g. as currently done in EXIOBASE) and potentially find better proxies.

\subsubsection{Spatial differentiation}

Currently, the inventory cannot be directly used to support air pollution modelling as the results are aggregated at national level and do not document emissions from individual facilities. Spatiallydifferentiated inventories could eventually be derived by using as proxies existing maps of the releases of a given substance from the power industry, such as the grid maps of greenhouse gas emissions published in EDGAR (EC JRC, 2017). Furthermore, knowing the activity of a given power plant, the present methodology could be adapted at facility level, and first estimates of the direct emissions could be calculated based on ecoinvent process inventories and additional emission factors. This could help derive more comprehensive inventories of pollutant emissions from individual power plants. 


\subsection{Implications for official reporting of national emissions}

As EMEP reports target specific substances, they cannot be used for comprehensive environmental impact assessment without the risk of obtaining biased results from omission of relevant damaging substances. Furthermore, with potential differences in their completeness across countries, the EMEP official reports are not suitable to compare the environmental impacts of heat and electricity production across different countries. As various methodologies can be used to build EMEP national reports, a verification procedure is required to prevent misreporting. The EMEP's existing review methodology includes 3 stages: (i) initial check of submissions for timeliness and completeness, (ii) assessment of all national submissions with regard to consistency and comparability of data, and (iii) indepth reviews of selected Parties' inventories (Mareckova et al., 2013). As part of stage (ii) in the review, national total emissions per capita and emissions per GDP are calculated, and the resulting outliers are flagged as potential indications of either errors in calculation or incomplete reporting. No comparability test is however performed at the sectoral level, e.g. sector of public heat and electricity production.

For the energy sector, comparing the EMEP national reports with empirically calculated pollutant releases as in the ENEE inventory could therefore help identify potential outliers and inconsistencies (see example in Section 3.2.2). It could thus be proposed to require from national authorities to flag their reported emissions with a justification whenever they report data differing significantly from the ENEE inventory, e.g. when it exceeds a certain percentage difference. Such thresholds could easily be determined at country and substance levels using the methodology applied in this study and the inventories for public heat and electricity production provided in Supporting Information A. 
Such approach could also be relevant for application to other public databases than EMEP. For example, the E-PRTR database may benefit from such application, in particular to help evaluate the completeness of the reporting of emissions to air (see Section 3.2.3).

\subsection{Implications for national inventories used in large-scale environmental footprinting}

Despite energy processes being among the most comprehensively covered in process LCI databases, our study identified a number of data gaps in terms of substance coverage in ecoinvent, together with some inconsistencies across countries. Likewise, EXIOBASE's coverage of toxic pollutants remains limited, and even though the most contributing substances are believed to be generally covered, the environmental impact results run the risk of being underestimated for some impact categories. By significantly expanding the coverage of pollutant emissions, the ENEE inventories provide a solid increase in the quality of data to support environmental footprints and large-scale LCAs for the energy sector. Such studies focus mostly on comparing several systems or identifying the top contributing processes in the supply chain at a given time (Laurent et al., 2018). In the absence of studies supporting further time or country differentiation of emission factors, the ENEE inventory can help improve the comprehensiveness in terms of substance coverage of satellite accounts included in EE-MRIO tables (such as EXIOBASE), where toxicity-related impacts are currently poorly covered (Mattila, 2018).

However, while electricity production is a major source of greenhouse gas emissions, its contribution to total national impacts such as freshwater eutrophication or freshwater ecotoxicity may be low in comparison to other sectors such as agriculture. The methodology presented and demonstrated here for the electricity and heat sector should thus also be applied to other sectors of the economy, where ecoinvent database has a good coverage of the central technologies and thus can serve as a good starting point to build robust national emission inventories. In particular, substance coverage 
should be expanded for sectors with a high potential for releasing toxic substances such as the metal industry or the agriculture, sources of metal and pesticide emissions respectively (Laurent et al., 2011; Sörme et al., 2016). This would support the development of national environmental footprints that encompass large parts of economy with a more complete coverage of not only airborne pollutant emissions but also releases to water and soil compartments, thus increasing the environmental relevance of the assessments and hence the reliability of the support provided to policy and decisionmakers in authorities.

\section{Associated Content - Supporting Information}

A Supporting Information is available. It contains:

- Supporting information A: Full ENEE inventories of pollutant emissions from main producers and autoproducers of heat and electricity in 140 countries in 1995-2014 (XLS).

- Supporting information B: documenting the detailed methodology and background data for the building of the ENEE inventory, as well as Supporting Figures B1-B10 and Tables B1-B9 to complement Results and Discussion sections (PDF).

\section{Acknowledgments}

The authors would like to thank Jeroen Kuenen (TNO) for his inputs on the TNO Emission Assessment (TEAM) Model. The authors have no conflict of interest to declare.

\section{References}

Bauer, C., 2017. Personal communication.

Beylot, A., Secchi, M., Cerutti, A., Merciai, S., Schmidt, J., Sala, S., 2019. Assessing the environmental impacts of EU consumption at macro-scale. J. Clean. Prod. 216, 382-393.

doi:10.1016/j.jclepro.2019.01.134 
Córdoba, P., Font, O., Izquierdo, M., Querol, X., Tobías, A., López-Antón, M.A., Ochoa-Gonzalez, R., DíazSomoano, M., Martínez-Tarazona, M.R., Ayora, C., Leiva, C., Fernández, C., Giménez, A., 2011. Enrichment of inorganic trace pollutants in re-circulated water streams from a wet limestone flue gas desulphurisation system in two coal power plants. Fuel Process. Technol. 92, 1764-1775. doi:10.1016/j.fuproc.2011.04.025

Cucurachi, S., Sala, S., Laurent, A., Heijungs, R., 2014. Building and Characterizing Regional and Global Emission Inventories of Toxic Pollutants. Environ. Sci. Technol. 48, 5674-5682. doi:10.1021/es405798x

Dones, R.; Bauer, C.; Bolliger, R.; Burger, B.; Heck, T.; Röder, A.; Faist Emmenegger, M.; Frischknecht, R.; Jungbluth, N.; Tuchschmid, M., 2007. Life Cycle Inventories of Energy Systems: Results for Current Systems in Switzerland and Other UCTE Countries. Ecoinvent Report No.5.; Dübendorf, CH.

EC, 2006. Regulation (EC) No 166/2006 of the European Parliament and of the Council of 18 January 2006 concerning the establishment of a European Pollutant Release and Transfer Register and amending Council Directives 91/689/EEC and 96/61/EC. Off. J. Eur. Union.

[dataset] EC JRC, 2017. Global Greenhouse Gases Emissions EDGAR v4.3.2. URL http://edgar.jrc.ec.europa.eu/overview.php?v=432_GHG (accessed 10.19.18).

[dataset] EEA, 2017. The European Pollutant Release and Transfer Register (E-PRTR), Member States reporting under Article 7 of Regulation (EC) No 166/2006 - Version 11. URL https://www.eea.europa.eu/data-and-maps/data/member-states-reporting-art-7-under-theeuropean-pollutant-release-and-transfer-register-e-prtr-regulation-14 (accessed 25.08.17)

[dataset] EMEP/CEIP, 2017. Officially reported emission data. URL http://www.ceip.at/ms/ceip_home1/ceip_home/webdab_emepdatabase/reported_emissiondata/ (accessed 9.19.17).

Fang, K., Heijungs, R., 2015. Investigating the inventory and characterization aspects of footprinting methods: lessons for the classification and integration of footprints. J. Clean. Prod. 108, 10281036. doi:10.1016/j.jclepro.2015.06.086

Frischknecht, R., 2005. From heterogenous databases to unified and transparent LCl data. Int. J. Life Cycle Assess. 10, 1-2. doi:10.1065/lca2005.01.001

Gingerich, D.B., Sun, X., Behrer, A.P., Azevedo, I.L., Mauter, M.S., 2017. Spatially resolved air-water emissions tradeoffs improve regulatory impact analyses for electricity generation. Proc. Natl. Acad. Sci. 114, 1862-1867. doi:10.1073/pnas.1524396114

Gómez, D.R., Watterson, J.D., Americano, B.B., Ha, C., Marland, G., Matsika, E., Namayanga, L.N., Osman-Elasha, B., Saka, J.D.K., Treanton, K., Quadrerlli, R., 2006. 2006 IPCC Guidelines for National Greenhouse Gas Inventories. Volume 2: Energy. Chapter 2: Stationary Combustion, 2006 IPCC Guidelines for National Greenhouse Gas Inventories.

Hauschild, M.Z., Huijbregts, M., Jolliet, O., Macleod, M., Margni, M., Ven de Meent, D., Rosenbaum, R.K., McKone, T.E., 2008. Building a Model Based on Scientific Consensus for Life Cycle Impact Assessment of Chemicals: The Search for Harmony and Parsimony. Environ. Sci. Technol. 42, 70327037. doi:10.1021/es703145t

Huijbregts, M.A.J., Steinmann, Z.J.N., Elshout, P.M.F., Stam, G., Verones, F., Vieira, M., Zijp, M., Hollander, A., van Zelm, R., 2017. ReCiPe2016: a harmonised life cycle impact assessment method 
at midpoint and endpoint level. Int. J. Life Cycle Assess. 22, 138-147. doi:10.1007/s11367-016$1246-y$

[dataset] IEA, 2016. Energy Balances: OECD \& Non-OECD. Paris, France.

IIASA, 2018. The GAINS model [WWW Document]. URL http://www.iiasa.ac.at/web/home/research/researchPrograms/air/GAINS.html (accessed 11.23.18).

ISO, 2006. Environmental management - Life cycle assessment - Principles and Framework. ISO 14040:2006. Geneva.

Kuenen, J., 2018. Personal communication.

Kuenen, J., Usubiaga, A., Acosta-Fernández, J., Merciai, S., 2015. DESIRE D5.3 Final Report Annex Emissions.

Laurent, A., Espinosa, N., 2015. Environmental impacts of electricity generation at global, regional and national scales in 1980-2011: what can we learn for future energy planning? Energy Environ. Sci. 8, 689-701. doi:10.1039/C4EE03832K

Laurent, A., Espinosa, N., Hauschild, M.Z., 2018. LCA of Energy Systems, in: Hauschild, M.Z., Rosenbaum, R.K., Olsen, S.I. (Eds.), Life Cycle Assessment. Theory and Practice. Springer International Publishing, pp. 633-668. doi:10.1007/978-3-319-56475-3

Laurent, A., Lautier, A., Rosenbaum, R.K., Olsen, S.I., Hauschild, M.Z., 2011. Normalization references for Europe and North America for application with USEtox ${ }^{\mathrm{TM}}$ characterization factors. Int. J. Life Cycle Assess. 16, 728-738. doi:10.1007/s11367-011-0285-7

Laurent, A., Olsen, S.I., Hauschild, M.Z., 2012. Limitations of carbon footprint as indicator of environmental sustainability. Environ. Sci. Technol. 46, 4100-4108. doi:10.1021/es204163f

Lenzen, M., 2011. Aggregation versus disaggregation in input-output analysis of the environment. Econ. Syst. Res. 23, 73-89. doi:10.1080/09535314.2010.548793

Manfred, C., Haider, S., Poupa, S., Mareckova, K., Seuss, K., Windhofer, G., Zechmeister, A., Fischer, C., Ryberg, M., Hofbauer, P., Milunov, M., Seyring, N., 2012. Three years of implementation of the EPRTR: Supporting study for the European Commission.

Mareckova, K., Pinterits, M., Tista, M., Wankmueller, R., 2016. Inventory Review 2016. Review of emission data reported under the LRTAP Convention and NEC Directive.

Mareckova, K., Wankmueller, R., Moosmann, L., Pinterits, M., Tista, M., Wankmueller, R., 2013. Methodology Report. Review of emission data reported under the LRTAP Convention and NEC Directive, Technical Report CEIP.

Mattila, T.J., 2018. Use of Input-Ouput Analysis in LCA, in: Hauschild, M.Z., Rosenbaum, R.K., Olsen, S.I. (Eds.), Life Cycle Assessment. Theory and Practice. Springer International Publishing, pp. 349-372. doi:10.1007/978-3-319-56475-3

Meij, R., te Winkel, H., 2007. The emissions of heavy metals and persistent organic pollutants from modern coal-fired power stations. Atmos. Environ. 41, 9262-9272.

doi:10.1016/j.atmosenv.2007.04.042 
Mokhtar, M.M., Taib, R.M., Hassim, M.H., 2014. Understanding selected trace elements behavior in a coal-fired power plant in Malaysia for assessment of abatement technologies. J. Air Waste Manag. Assoc. 64, 867-878. doi:10.1080/10962247.2014.897271

Nielsen, M., Nielsen, O.-K., Hoffmann, L., 2013. Improved inventory for heavy metal emissions from stationary combustion plants. 1990-2009.

Nielsen, O.-K., Plejdrup, M., Rentz, O., Oertel, D., Woodfield, M., Stewart, R., 2016. 1.A.1 Energy industries, in: EMEP/EEA Air Pollutant Emission Inventory Guidebook 2016. Copenhagen, pp. 1-38. doi:10.2800/247535

Oita, A., Malik, A., Kanemoto, K., Geschke, A., Nishijima, S., Lenzen, M., 2016. Substantial nitrogen pollution embedded in international trade. Nat. Geosci. 9, 111-115. doi:10.1038/ngeo2635

Persson, L., Arvidsson, R., Berglund, M., Cederberg, C., Finnveden, G., Palm, V., Sörme, L., Schmidt, S., Wood, R., 2019. Indicators for national consumption-based accounting of chemicals. J. Clean. Prod. 215, 1-12. doi:10.1016/j.jclepro.2018.12.294

Prell, C., Feng, K., Sun, L., Geores, M., Hubacek, K., 2014. The economic gains and environmental losses of US consumption: A world-systems and input-output approach. Soc. Forces 93, 405-428. doi:10.1093/sf/sou048

Rosenbaum, R.K., Bachmann, T.M., Hauschild, M.Z., Huijbregts, M.A.J., Jolliet, O., Juraske, R., Koehler, A., Larsen, H.F., Macleod, M., Margni, M., Mckone, T.E., Payet, J., Schuhmacher, M., Van De Meent, D., Hauschild, M.Z., 2008. USEtox : UNEP-SETAC recommended characterisation model and factors for human toxicity and freshwater ecotoxicity in LCIA. Int. J. Life Cycle Assess. 13, 532-546. doi:10.1007/s11367-008-0038-4

Schandl, H., Hatfield-Dodds, S., Wiedmann, T., Geschke, A., Cai, Y., West, J., Newth, D., Baynes, T., Lenzen, M., Owen, A., 2016. Decoupling global environmental pressure and economic growth: scenarios for energy use, materials use and carbon emissions. J. Clean. Prod. 132, 45-56. doi:10.1016/j.jclepro.2015.06.100

Sörme, L., Palm, V., Finnveden, G., 2016. Using E-PRTR data on point source emissions to air and waterFirst steps towards a national chemical footprint. Environ. Impact Assess. Rev. 56, 102-112. doi:10.1016/j.eiar.2015.09.007

Stadler, K., Wood, R., Bulavskaya, T., Södersten, C.-J., Simas, M., Schmidt, S., Usubiaga, A., AcostaFernández, J., Kuenen, J., Bruckner, M., Giljum, S., Lutter, S., Merciai, S., Schmidt, J.H., Theurl, M.C., Plutzar, C., Kastner, T., Eisenmenger, N., Erb, K.-H., de Koning, A., Tukker, A., 2018. EXIOBASE 3: Developing a Time Series of Detailed Environmentally Extended Multi-Regional Input-Output Tables. J. Ind. Ecol. 22, 502-515. doi:10.1111/jiec.12715

Steffen, W., Richardson, K., Rockström, J., Cornell, S.E., Fetzer, I., Bennett, E.M., Biggs, R., Carpenter, S.R., De Vries, W., De Wit, C.A., Folke, C., Gerten, D., Heinke, J., Mace, G.M., Persson, L.M., Ramanathan, V., Reyers, B., Sörlin, S., 2015. Planetary boundaries: Guiding human development on a changing planet. Science. 347. doi:10.1126/science.1259855

Su, B., Ang, B.W., 2010. Input-output analysis of CO2 emissions embodied in trade: The effects of spatial aggregation. Ecol. Econ. 70, 10-18. doi:10.1016/j.ecolecon.2010.08.016

Tong, D., Zhang, Q., Davis, S.J., Liu, F., Zheng, B., Geng, G., Xue, T., Li, M., Hong, C., Lu, Z., Streets, D.G., Guan, D., He, K., 2018. Targeted emission reductions from global super-polluting power plant units. 
Nat. Sustain. 1, 59-68. doi:10.1038/s41893-017-0003-y

Trozzi, C., Rentz, O., Oertel, D., Woodfield, M., Stewart, R., 2010. 1.A.1 Energy industries, in: EMEP/EEA Air Pollutant Emission Inventory Guidebook 2009.

Tukker, A., Koning, A. De, Wood, R., Hawkins, T., Lutter, S., Acosta, J., Rueda Cantuche, J.M., Bouwmeester, M., Oosterhaven, J., Drosdowski, T., Kuenen, J., De Koning, A., 2013. EXIOPOL Development and illustrative analyses of a detailed global MR EE SUT/IOT. Econ. Syst. Res. 25, 5070. doi:10.1080/09535314.2012.761952

UNECE, 1979. 1979 Convention On Long-Range Transboundary Air Pollution.

[dataset] UNFCCC, 2017. Greenhouse Gas Inventory Data - Detailed data by Party. URL https://di.unfccc.int/detailed_data_by_party (accessed 9.19.17).

United Nations, 2016. Sustainable Development Goal 12.

Urashima, K., Chang, J.S., 2000. Removal of volatile organic compounds from air streams and industrial flue gases by non-thermal plasma technology. IEEE Trans. Dielectr. Electr. Insul. 7, 602-614. doi:10.1109/94.879356

US EPA, 2010. AP-42 Section 1.3 Fuel Oil Combustion.

US EPA, 2003. AP-42 Section 1.6 Wood Residue Combustion in Boilers.

US EPA, 1998a. AP-42 Section 1.1 Bituminous and Subbituminous Coal Combustion.

US EPA, 1998b. AP-42 Section 1.4 Natural gas combustion.

US EPA, 1998c. AP-42 Section 1.7 Lignite Combustion.

US HHS, 2016. 14th Report on Carcinogens, Occupational Medicine.

Verones, F., Moran, D., Stadler, K., Kanemoto, K., Wood, R., 2017. Resource footprints and their ecosystem consequences. Sci. Rep. 7, 40743. doi:10.1038/srep40743

Wang, A., Song, Q., Tu, G., Wang, H., Yue, Y., Yao, Q., 2014. Influence of flue gas cleaning system on characteristics of PM2.5emission from coal-fired power plants. Int. J. Coal Sci. Technol. 1, 4-12. doi:10.1007/s40789-014-0001-x

Weidema, B.P., Bauer, C., Hischier, R., Mutel, C., Nemecek, T., Reinhard, J., Vadenbo, C.O., Wernet, G., 2013. Overview and methodology. Data quality guideline for the ecoinvent database version 3. ecoinvent Report 1(v3). St. Gallen: The ecoinvent Centre.

Wenborn, M., Coleman, P., Passant, N., Lymberidi, E., Sully, J., Weir, R., 1999. Speciated PAH inventory for the UK.

Wernet, G., Bauer, C., Steubing, B., Reinhard, J., Moreno-Ruiz, E., Weidema, B., 2016. The ecoinvent database version 3 (part I): overview and methodology. Int. J. Life Cycle Assess. 21, 1218-1230. doi:10.1007/s11367-016-1087-8

Wiedmann, T., 2009. A review of recent multi-region input-output models used for consumption-based emission and resource accounting. Ecol. Econ. 69, 211-222. doi:10.1016/j.ecolecon.2009.08.026 
Wood, R., Stadler, K., Bulavskaya, T., Lutter, S., Giljum, S., de Koning, A., Kuenen, J., Schütz, H., AcostaFernández, J., Usubiaga, A., Simas, M., Ivanova, O., Weinzettel, J., Schmidt, J.H., Merciai, S., Tukker, A., 2015. Global sustainability accounting - developing EXIOBASE for multi-regional footprint analysis. Sustainability 7, 138-163. doi:10.3390/su7010138 


\section{Building national emission inventories for the energy sector: Implications for life cycle assessment and nations environmental footprinting}

Alexandra Leclerc, Michael Z. Hauschild, Richard Wood, Alexis Laurent

Highlights:

- We built a global inventory of direct releases from heat and electricity production

- An unprecedented coverage of 231 substances to air and 87 to water was reached

- Inventory completeness is critical to assess all environmental impact categories

- Priority chemicals to be included in national inventories were identified 


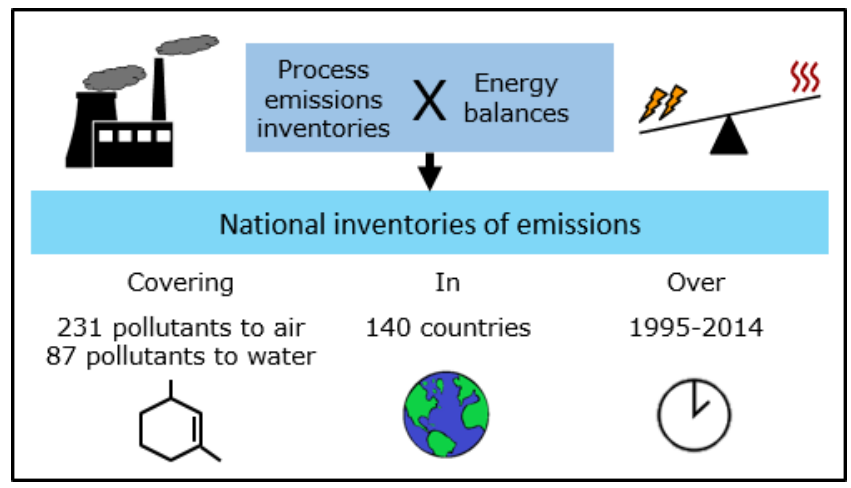

